\title{
ANDEAN LAND USE AND BIODIVERSITY: HUMANIZED LANDSCAPES IN A TIME OF CHANGE
}

\author{
Author(s): Kenneth R. Young
}

Source: Annals of the Missouri Botanical Garden, 96(3):492-507.

Published By: Missouri Botanical Garden

DOI: http://dx.doi.org/10.3417/2008035

URL: http://www.bioone.org/doi/full/10.3417/2008035

BioOne (www.bioone.org) is a nonprofit, online aggregation of core research in the biological, ecological, and environmental sciences. BioOne provides a sustainable online platform for over 170 journals and books published by nonprofit societies, associations, museums, institutions, and presses.

Your use of this PDF, the BioOne Web site, and all posted and associated content indicates your acceptance of BioOne's Terms of Use, available at www.bioone.org/ page/terms of use.

Usage of BioOne content is strictly limited to personal, educational, and noncommercial use. Commercial inquiries or rights and permissions requests should be directed to the individual publisher as copyright holder. 


\section{ANDEAN LAND USE AND \\ Kenneth R. Young ${ }^{1}$ \\ BIODIVERSITY: HUMANIZED \\ LANDSCAPES IN A TIME OF \\ CHANGE}

\section{ABSTRACT}

Some landscapes cannot be understood without references to the kinds, degrees, and history of human-caused modifications to the Earth's surface. The tropical latitudes of the Andes represent one such place, with agricultural land-use systems appearing in the Early Holocene. Current land use includes both intensive and extensive grazing and crop- or tree-based agricultural systems found across virtually the entire range of possible elevations and humidity regimes. Biodiversity found in or adjacent to such humanized landscapes will have been altered in abundance, composition, and distribution in relation to the resiliency of the native species to harvest, land cover modifications, and other deliberate or inadvertent human land uses. In addition, the geometries of land cover, resulting from differences among the shapes, sizes, connectivities, and physical structures of the patches, corridors, and matrices that compose landscape mosaics, will constrain biodiversity, often in predictable ways. This article proposes a conceptual model that implies that the continued persistence of native species may depend as much on the shifting of Andean landscape mosaics as on species characteristics themselves. Furthermore, mountains such as the Andes display long gradients of environmental conditions that alter in relation to latitude, soil moisture, aspect, and elevation. Global environmental change will shift these, especially temperature and humidity regimes along elevational gradients, causing changes outside the historical range of variation for some species. Both land-use systems and conservation efforts will need to respond spatially to these shifts in the future, at both landscape and regional scales.

Key words: Andes, climate change, human impact, land use, land use/land cover change, landscape ecology.

Humankind has lived on the Earth, and thus altered parts of it, for millennia-in the case of the Old World, for several million years. In such long-inhabited landscapes, the nature of the influence of people through their land uses on native plants and animals, and on the living land cover provided by vegetation, is important to evaluate. For example, it matters greatly if deforestation began 40 years ago due to the entrance of colonists with chain saws, or if current land cover modifications are in fact affecting a landscape reforested following a previous but ancient forest clearance. Often, detailed historical information on past land use will not be readily available, but an awareness of possible consequences is feasible, desirable, and useful for calibrating efforts for biodiversity conservation and for planning for resource sustainability. This article begins to assemble the information needed to prepare for the consequences of changed future environments in the Andean landscapes.

The conservation of biodiversity has spatial dimensions that range from global concerns to the genes of particular subspecies, land races, or individuals. This multiscalar quintessence results from the fact that biodiversity (biological diversity) includes not only species but the populations and genetic systems that underlie those species, in addition to multispecies assemblages, communities, and ecosystems (Noss, 1990; Franklin, 1993). A scale, and also an organizational level, of particular relevance to land use and to inhabited places in general is that of the landscape, typically taken in this context to refer to an area of the Earth's surface tens to several hundreds of square kilometers in size (Turner, 2005). This article examines Andean landscapes where that amount of surface area includes the size range that accommodates the dimensions of landscapes used by a particular owner, family, community, or organization. In addition, landscapes are at a human scale with which to observe, organize, and conceptualize the Earth's surface, as seen, e.g., in the prevalence of landscape photographs and paintings. Landscape ecology provides a conceptual framework, a vocabulary, and a set of paradigmatic expectations that can be used to classify and quantify the shifting of land cover types in a particular place (Young \& Aspinall, 2006).

This article uses a landscape approach to consider some of the implications of human impacts, current and past, in the Andes. It begins with an overview of how the Earth's surface can be evaluated in terms of landscape mosaics (Forman, 1995), especially in mountainous regions, taking examples from other places in the world when the relevant studies have yet

\footnotetext{
${ }^{1}$ Department of Geography and the Environment, University of Texas, Austin, Texas 78712, U.S.A. kryoung@austin. utexas.edu.
}

doi: $10.3417 / 2008035$

Ann. Missouri Bot. Gard. 96: 492-507. Published on 28 September 2009. 
to be done in the Andes. Often, a landscape ecology approach is conceptualized strictly in terms of ecological processes, but this article also situates the Andean landscapes within regional and geological contexts, with their respective spatial and temporal scales. It is also important to identify landscape legacies that continue to alter biophysical conditions for species today (cf. Foster et al., 2003). These legacies and current land-use practices contribute to humanizing parts of the Andes, remade into utilized and inhabited spaces (Troll, 1968; Ellenberg, 1979). Finally, this information is used to propose a conceptual model of what kinds of places and what kinds of species are most threatened with future extinctions - a topic of considerable importance for the Andes, where species loss is occurring (Pitman et al., 2002; Pounds et al., 2006).

\section{Landscape Ecology in the Andes}

Land cover varies from place to place in ways that can be measured, mapped, and modeled. In a given Andean landscape, or indeed for most any terrestrial landscape, underlying environmental heterogeneity in soil characteristics such as moisture, depth, and chemistry can alter the species composition, density, and life forms of plants dominating local tracts of vegetation (e.g., Clark et al., 1998; Svenning, 2001), in addition to the associated soil biota and edaphic processes (Wardle, 2002; Vanbergen et al., 2007). Over slightly larger extents, there will be streams, ponds, or rock outcrops that form or support differing substrates that add additional spatial heterogeneity to land cover (e.g., Ibarra-Manríquez \& Martínez-Ramos, 2002; Dwire et al., 2004). Disturbances, as minor as those caused by the falling of limbs from a large tree or as intense as fires that burn plants and leaf litter down to mineral soil, create patches of open habitat. Destructive storms can have landscape consequences over regions subjected to freezing rain (Stueve et al., 2007); volcanoes can set the biophysical features that then control post-disturbance vegetation and ecosystem processes (Vitousek, 2004). Those open sites can be colonized by plant species that are easily dispersed or that grow in quickly from gap edges.

Disturbance gaps that result from the physical removal of land cover and the biogeochemical alteration of perturbed sites allow a variety of fugitive, successional, and other species to survive in a given landscape (Wilcox et al., 2006). Plant diseases similarly both move in response to spatial heterogeneity and also help to create and maintain heterogeneity (Plantegenest et al., 2007). Disturbance and successional dynamics thus act upon the living land covers formed by native vegetation types, creating landscape mosaics that can be characterized in terms of changes along spatial gradients in underlying biophysical constraints, in addition to the dynamism imposed by plant death and regrowth (e.g., Velázquez \& Gómez-Sal, 2007).

Important coupled feedbacks tie in other trophic levels that can act to reinforce landscape spatial heterogeneity or, alternatively, to lessen it. Herbivores, for example, may remove much biomass of palatable species, altering dominance or even shifting one vegetation type to another (e.g., Dorrough et al., 2007). Often, plant species growing in a disturbancecaused gap lack the plethora of herbivore defenses found in undisturbed sites (Coley \& Barone, 1996), so herbivore impact is spatially heterogeneous in itself (e.g., Forester et al., 2007). The same would be true of the degree and influence of mutualistic relationships such as those between flowering plants and their pollinators (e.g., Muchhala \& Jarrín-V., 2002) or between plants with fruits attractive to birds, monkeys, or bats and their vertebrate dispersers (Palacios \& Rodriguez, 2001; Rodríguez-Cabal et al., 2007). Predators can exert top-down influences with landscape consequences (Ripple et al., 2001; Smith et al., 2003; Schmitz, 2008).

Many human impacts leave conspicuous alterations on landscapes, with cover modified into housing, roads, pastures, or tree plantations. Other influences, however, may be more subtle, with forests still dominated by native species, but with the seed dispersers and seed predators rearranged in their abundances by hunting and harvesting: leaving behind what Redford (1992) called empty forests, which, as a result, will have altered future forest successional trajectories. Bodin et al. (2006) showed that even small forest patches in otherwise deforested areas of Madagascar provided important environmental services for local people.

All these features of spatial heterogeneity and landscape dynamism characterize the Andes (Young et al., 2007; Young, 2008). Complete explanations of spatial and temporal change will necessarily need to consider or control for all of these edaphic, vegetational, and ecological processes, in addition to human land use itself. Consider, for example, the landscape in Figure 1. The spatial heterogeneity most visible is imparted by the patchwork of houses and agricultural fields. Because the dominant land cover type includes the different kinds of agricultural fields, this could be called the landscape matrix, with additional patches in that matrix of trees and of the settlement. Clearly, much explanation of the details of this mosaic landscape patterning would require data regarding human decisions on when and where the residents chose to live and decided what to grow. The social 


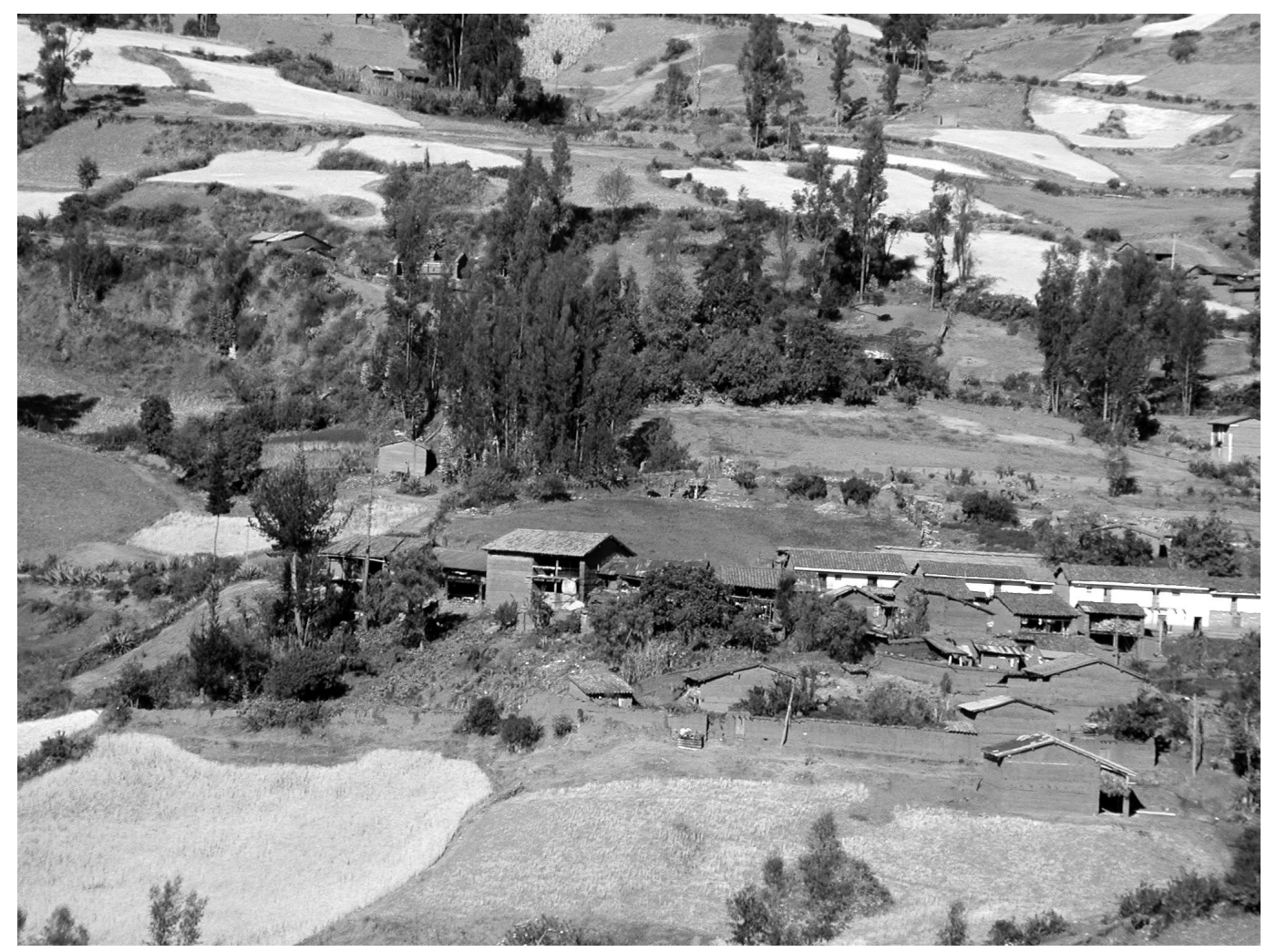

Figure 1. Humanized landscape in the Peruvian Andes showing houses, planted trees, and agricultural fields.

sciences would need to provide many of the research paradigms. However, even this intensively used (humanized) landscape has an important underlying spatial heterogeneity that comes from minor changes in elevation, topography, and soils. Landscape ecology increasingly draws from relevant social, behavioral, and economic theories in providing explanations of patterns and processes.

Global environmental change will alter connectivity among different land cover patches, along environmental gradients, and within the landscapes themselves. Often, species are found in areas much larger than a landscape, so that their overall range distributions will be changed in relation to their environmental tolerances, with cold-adapted species shifted to higher elevations and moisture-requiring species pushed into humid refugia (Golicher et al., 2008). Particular landscapes may be relatively buffered from change. In others, however, species dominance can be expected to change, leading to numerous feedbacks and shifts to and through trophic systems, with consequences for ecosystem processes. There are also important scalar considerations that arise for the Andean landscapes of interest.

\section{Temporal Scales in Andean Landscapes}

Landscape dynamism includes temporal shifts in the different spatial elements that make up the mosaic: the patches, the matrix background, and the long, linear features that form corridors. Seasonality can cause minor shifts in those patterns, with leaf fall and flush coordinated with the start and end, respectively, of dry or cold seasons. Changing seasons also bring in their wake different biophysical stresses or cause different kinds or degrees of disturbances. In addition, long-term monitoring often reveals subdecadal oscillations-for example, the El Niño-Southern Oscillation causes such repeated effects through the increased rain or drought that occurs, depending on the location. Indeed, work in Argentina has revealed subdecadal variations in fire that result from El Niño rains but that occur one to two years later, because that is when maximum biomass is available as fuel for fires causing lagged effects (Grau, 2001; see also Kitzberger et al., 2007).

Temporal shifts cause a variety of ecological responses, from physiological adjustments in individual plants to shifts in landscape patchiness over 
decades or centuries. Over evolutionary time, as measured in millennia or in relation to the number of generations per unit time (e.g., 1/100 years for a tree species), population sizes and their rates of interpopulation gene flows vary with the size of patches of habitat, which controls the number of individuals in particular patches, and with their interpatch distances, which affect the degree of connectivity and amount of dispersal. As such, there is a temporal scale to landscape phenomena connecting metapopulation dynamics and ecological and evolutionary processes. Thus, edaphic differences in a tropical forest may give rise not only to different vegetation types as mediated through herbivores in ecological time, but over evolutionary time to different plant lineages (e.g., Fine et al., 2004). These considerations shape how different landscapes interact over evolutionary time, potentially allowing Earth system science and evolutionary biology to inform the landscape ecology of the Andes. In addition, the study of landscape genetics is developing promising research approaches (Manel et al., 2003), as is the use of graph (Brooks, 2006; Ferrari et al., 2007) and circuit theory (McRae \& Beier, 2007).

Geological history reveals shifts in connectivity and extent of different elevational or life zones in the Andes over very long time spans, with additional dynamism originating with global climate changes and their local and regional consequences (e.g., Montgomery et al., 2001). The Andes include rocks laid down as sediment more than 100 million years ago (Ma). As they rose and folded or faulted, these rocks were transformed over wide areas into their metamorphic derivatives, often alongside additional rock material forming from the cooling of magma and lava forced up from the subsiding Pacific and Caribbean plates. Their rise was episodic, with long periods of stasis followed by relatively rapid periods of heightening (Garzione et al., 2008). Given this extended and ancient history, no doubt there are many legacies among the Andean flora and fauna resulting from these past geographies, distinctive connectivities, and altered climates that have shaped speciation, promoted endemism, and caused extinctions of some lineages (Young et al., 2002). There are a variety of dry forest plant groups found with fragmented ranges in intermountain valleys and on both sides of the Andes, which have been shown (Pennington et al., 2006) to reflect this colorful geological past. At least some of the genera of Annonaceae found on both sides of the Andes come from dispersal and speciation events estimated by Pirie et al. (2006) to be 10-60 Ma.

However, uplift, volcanism, and other results of tectonics continue to this day in the Andes (Veblen et al., 2007). As a result, some biodiversity patterns are due to much more recent and even ongoing speciation processes. Andean landscapes often have spatial characteristics that promote the separation and subdivision of species habitat patches. For example, Hughes and Eastwood (2006) show that the Andean members of Lupinus L. (Fabaceae) may result from speciation occurring at some of the fastest rates ever documented (2.49 to 3.72 species/1,000,000 years). They suggest that this alacrity was fostered by the repeated development of newly available islandlike habitats at high elevations in the Andes, caused by Quaternary glaciation cycles. In addition, much of the fastest uplift of the Andes has been in the recent geological past, increasing the elevations of the highest cordilleras by more than $2000 \mathrm{~m}$ compared with their maximum heights in the Tertiary (Graham et al., 2001). Hughes and Eastwood (2006) suggest that resulting rapid speciation is behind high diversity in a variety of Andean plant genera. Muellner et al. (2005) begin to sort the details explaining current genetic structure of an Andean composite, Hypochaeris palustris (Phil.) Wildeman, as caused by differential colonization and survival in refugia. Brumfield and Edwards (2007) suggest similarly complex routes to speciation and occupation of Andean forests by Thamnophilus Vieillot antshrikes, while Torres-Carvajal (2007) shows relatively recent divergence and speciation out of the central Andes by Stenocercus Duméril \& Bibron lizards. Andean landscapes and regions contain legacies of these evolutionary processes. Changes outside the historical range of biophysical variation may cause future extinctions of particular species.

\section{Spatial Dimensions Operating in Andean Landscapes}

There is also a spatial and scalar aspect to consider as the biodiversity found in a particular landscape will be a subset of that found in the surrounding region, unless they are equal, as can happen in species-poor biomes. The regional context matters; adjacent areas with high connectivity, past or present, share more species with the landscape of interest. Regional connectivity thus influences or controls the composition and evolutionary dynamics of the species to be found in a particular place.

Broad-scale and gradient variables also affect landscapes and species populations (Talley, 2007). For mountains, regional context comes from upland to lowland connections and cross-mountain range influences (Gentry, 1982), in addition to along-cordillera shifts (e.g., Graves, 1988; Rull \& Nogué, 2007). Called continua by Seastedt et al. (2004), these spatial transitions provide differential amounts of available habitat and source areas. The continua delimit possible configurations of embedded landscapes; they 
influence biodiversity in spatial ways, increasing beta diversity and other place-to-place heterogeneity (e.g., Kattan et al., 2006) and affecting genetic variation (Ohsawa \& Ide, 2008). Change in elevation in the Andes produces a series of interrelated shifts in atmospheric gases, solar radiation, wind, temperature ranges, and soil moisture (Körner, 1999), not to mention in species composition (e.g., Terborgh, 1971; La Torre-Cuadros et al., 2007; Sergio \& Pedrini, 2007).

The connections of highlands to contiguous lowlands potentially allow those lowlands to serve as sources of colonizing species over long time periods. More important, however, are the long but narrow connections to mountains on the same cordillera, while continued orogenies create potential new habitat for dispersing montane or alpine species. Yet another characteristic of mountains is great site-to-site change in biophysical factors in elevation as well as different bedrocks and aspects. As a result, most any place in high mountains is only a short vertical distance from lowlands, a short horizontal distance from a wetter (or drier) microsite, and centimeters from a slightly different altitude. Distance and dispersal barriers among potential habitat patches become critical features (e.g., Graf et al., 2007).

Barriers that restrict species ranges can split populations and reduce gene flow. Such species may be found in metapopulations characterized by subpopulations linked by occasional dispersal events, affected by local extinctions in particular habitat patches, and with some individuals in marginal or sink habitats. Some of the resulting legacies become conservation priorities (Young et al., 2002). A recent example by Marín et al. (2007) evaluates the phylogeography of vicuña in conservation terms, with evidence of a rapid relatively recent northern range expansion into northern Peru, but with older multiple lineages across the southern distribution limit in Chile and Argentina. Anciently surviving lineages are found among several of the genera endemic to the Andes; some rare Andean species are paleoendemics. These kinds of biologic uniqueness warrant special conservation efforts directed toward taxa without close-living sister groups or centered on the places where they may be endemic. If recent events have caused range reductions or fragmentations, or if there is rapid speciation into archipelago-like habitats, then numerous neoendemics will be present. These species might best be protected by conservation directed at the habitats and places of concern, as presumably the processes behind diversification would also be conserved under those conditions. However, an additional source of spatial heterogeneity comes from Andean land-use systems of intensively farmed plots and gardens, with extensively used rangelands and croplands.

\section{Humanized Landscapes of the Andes}

Humans alter land cover and hence landscape mosaics. Thus, part of the key to understanding future changes in the Andes may come from deciphering anthropogenic influences on these kinds of mosaics, mosaic-related phenomena, and mosaic-influencing processes. Ecologic effects in this context would be those affecting species composition and abundance in particular patches and those that alter connectivity among patches. Connectivity for a particular species is affected by the distance, presence, type of dispersal corridor, and type of land cover that composes the matrix (e.g., Kupfer et al., 2006; Nascimento et al., 2006). The type and location of remaining habitat can be a critical feature for surviving native biodiversity (e.g., Devictor \& Jiguet, 2007), as is the presence of corridors (Chetkiewicz et al., 2006). Over evolutionary time spans, mosaic landscapes would host variable population sizes and connectivities, which are prime precursors of both extinction and speciation processes for native plants and animals. Humans can cause species extinctions in a matter of years or decades in particular landscapes, while their effects on selection pressures will be a function of the intensities or directions of those pressures and the generation time of the species of concern. There has been inadvertent selection pressure brought to bear on thousands of species due to modifications of habitat through land use and anthropogenic climate change (e.g, Reusch \& Wood, 2007; Araújo et al., 2008).

Humanized landscapes are those that are altered in ways that satisfy human needs and goals. Kareiva et al. (2007) postulated that these kinds of modifications made to inhabited landscapes can be considered reminiscent of species domestication by humans, with similar benefits of maximized food production, increased control, and reduced risks of time periods without food, fibers, or fuels. Vulnerability of people to natural hazards in inhabited landscapes of the Andes can be reduced through manipulation of slopes, redirection of rivers, and other farming or engineering approaches (Young \& León, 2009). Control of predators through hunting or of pests through pesticides may be augmented by removal of required habitat. Some insect pests of agricultural concern are kept controlled by native predators surviving in edge and matrix habitat (Rand et al., 2006).

While it is commonplace to lament the destructive influences of people on biodiversity, in cultural contexts such as in regard to long-inhabited landscapes of the Andes, there is in fact an increase in some kinds of diversity — for example, as measured in overall habitat diversity or in terms of the genotypes and phenotypes of domesticated plants and animals. 
Humans worldwide have brought several hundred species into domestication, shaping their genotypes to create desired phenotypes and products. Several kinds of wheatlike grasses from the eastern Mediterranean were crossed and bred to produce wheat that feeds millions of people today (Salamini et al., 2002). The availability of rice selected for different flooding regimes permits farming on a wide variety of terrains with dry land, wetland, or controlled paddy conditions (Carney, 1991; Khush, 1997). The diversity extant among domesticated guinea pigs that originate from the Andes is useful in laboratories around the world (Spotorno et al., 2006). This kind of agrobiodiversity is considered highly threatened, as much of it is maintained because of agricultural practices supported by cultural norms that may change in the future (Brush, 2000; Young, 2002).

Efforts to promote sustainable land-use practices in the future no doubt would be better informed if they were based on considerations of which practices have proved long-lived and which practices have resulted in undesirable consequences. Agriculture in Europe arose from land-use practices and associated worldviews originating in the Mediterranean-from Greek, Roman, Arab, and other civilizations and influences (Glacken, 1976). Mediterranean shrubland might have been derived from previously forested landscapes that were deforested for timber and agriculture several millennia ago, then maintained in scrub through burning and grazing for livestock (Blondel, 2006; Henkin et al., 2007), with bouts of soil erosion (Butzer, 2005). In the case of the Andes, much change in land cover happened several millennia ago.

Recently, an evaluation of current spatial patterns of vegetation in a site in France concluded that presentday edaphic conditions were not sufficient to explain the patterns found; instead, there were legacies dating back to land use during the Roman conquest that were affecting modern vegetation patterns (Dambrine et al., 2007). A similar finding was made by Pärtel et al. (2007) for explanations of the amount of floristic diversity in calcareous grasslands of Europe in relation to settlements 1000 years BP. It is perhaps ironic that a botanist would need to be conversant with the archaeology of classical antiquity and the Iron Age to understand the causalities at play. Similarly, the origins of current land-use practices in Papua New Guinea can be traced back to $11,000-7000$ years BP, when forests and wetlands were converted for croplands (Hope \& Tulip, 1994). The Australian outback was settled more than 50,000 years ago with fire becoming a tool of landscape change used by people, although details on the relative importance of the anthropogenic influence on the loss of native species are still controversial (Bowman, 1998).
In the Andes, Dillehay et al. (2007) showed that people were using field agriculture by 9200 years BP. By using dated plant remains from archaeological sites in northern Peru at sites at $500 \mathrm{~m}$ elevation, Dillehay et al. also showed cultivation of squash earlier than 9000 years BP, the peanut by at least ca. 7800 years BP, and cotton by ca. 5500 years BP. The Andean landscapes began to be altered in terms of land cover, accompanied by the domestication of wild species and manipulation of land races. There are archaeological remains of fields in that study area with furrows and evidence of irrigation through canals, suggesting social organization of interdependent households by those time periods. Similar kinds of data are available for landscapes in southern Peru (Perry et al., 2006) and generally in the tropical Andes (Denevan, 2001). Paduano et al. (2003) found many weedy plant species in the pollen record of Lake Titicaca sediments beginning ca. 3100 years BP, while Chepstow-Lusty et al. (Chepstow-Lusty \& Winfield, 2000; Chepstow-Lusty et al., 2003) report abundant Ambrosia L. and Chenopodiaceae pollen from $2200 \mathrm{BCE}$ to $750 \mathrm{BCE}$ in the Cusco area, along with evidence of ancient agroforestry.

Because there are multiple possible combinations of land use and land cover, often their study through time is referred to as research on land-use/land-cover change (LULCC) (Lambin et al., 2001, 2003; Young, 2005). An agent of landscape change can be a person, household, town, or natural agent such as an insect pest or a windstorm. A driver of landscape change may be the economic system or financial event that motivates the people involved, or perhaps a shifting air circulation system that alters the trajectory of a storm that then results in windthrow of tall trees. The landscape mosaic, classifiable into land-use/landcover units and spatially delineated into patches and corridors, can be tied conceptually to theories and data, in this particular case, on economics and on atmospheric physics. Land change science draws on a wide range of social, biological, and physical sciences for paradigms and explanations (Gutman et al., 2004). Kintz et al. (2006) used this approach to map and quantify change in landscape mosaics of northern Peru over a 13-year period. Most change was related to altered land use as local population size doubled with in-migration. Another component of change was the national park management, and possibly some vegetation shifts were caused directly by climate change. Postigo et al. (2008) recently also used satellite-derived mapping to locate how climate change in south-central Peru was altering land cover that is useful for high-elevation pastoralists. However, some land-use changes were motivated by prices for products from their alpaca and sheep, while still 
others are the result of partial out-migration of many members of the households and families.

\section{ANDEAn Landscape Legacies}

Legacies of a long history of changes in agriculture and land cover in the Andes can be found in many landscape characteristics (Fig. 1). Soils, for example, can show topographic and micromorphologic features caused by past cultivation and terracing (Sandor \& Eash, 1995; Kemp et al., 2006). Similar dated features in a study by Rigsby et al. (2003) reveal human occupation of flat topographic features beginning 10,000 years BP and continuing in the evolving landscapes of southern Peru on different terrain features for the next 10 millennia. Without terracing or following its abandonment, cultivation often results in increased soil erosion (Inbar \& Llerena, 2000).

Fire is another source of landscape dynamism. Fire is a natural agent of change in the Andes; however, it is often provoked by lightning strikes, so ignition caused by nature may frequently be limited to the rainy season. As a result, much burning and extensive fires are instead due to human agency, which began several millennia ago. People arrived in South America in the Early Holocene carrying stone weapons, accompanied by dogs, and using fire. Fire as recorded in carbonized wood particles in dated lake sediments can be documented back as far as records reach in Lake Titicaca to 27,500 years BP (Paduano et al., 2003). However, there is an obvious human imprint on the abundance of charcoal in some Andean lakes. For example, Bush et al. (2005) showed a time period ca. 3500 years BP when charcoal dramatically increased. Because they were able to separate out the principle climate-caused shifts caused by a multidecadal precipitation oscillation by using wavelet analysis, other changes, such as this charcoal increase, would presumably be anthropogenic in causality.

Millennia of Andean agriculture were interrupted by the impact of contact and conquest by Europeans 500 years BP, followed by abrupt declines in human population numbers and then the incorporation of new domesticated species and the development of novel land uses as rural populations slowly recovered (Gade, 1999; Sarmiento, 2003). Colonialism has continued consequences for landscapes (Sluyter, 2001). Because the Spanish were concerned with control of their colonies, they imported and imposed land use as mediated through households clustered into towns and centered on a plaza with a church and administrative buildings. These settlements, known as "reducciones," concentrated houses into small urban areas and were accompanied by altered economic goals for the people, often involving the provision of taxes, products, or labor to regional or national governments. Both land use and land cover changed.

Today, Andean landscapes not on the wet external flanks of the Andes are dominated by shrubs, not by trees (Fig. 1; Young, 1998). Thus, many Andean landscapes have a shrubland matrix, with remaining forest patches accompanied by other patches containing planted and fallowed fields. Species in those patches will have their local populations shaped by the area, number, and separation of the respective patches. Indeed, in many Andean landscapes, dominant trees are not native species, but are planted eucalypts or pines, which may eliminate some native species due to missing mutualists. Structural features of these humanized landscapes include rock walls, terraces, forest patches, trails, fallow fields, pastures, and house gardens. These land cover types delimit patches of varying value to people for the extraction of firewood and medicinal plants and the production of field crops, fruit trees, and livestock. Fire continues to be used to reduce woody cover and foment sprouting of palatable plants for grazing over extensive areas, even those far from settlements. Andean land use is typically intensive locally around houses and extensive over hillsides and on mountain peaks.

Surviving native species of plants of these landscapes often have small, well-dispersed seeds; can resprout following apical damage; may have thorns or other protection; and are either resilient or inconspicuous (Laegaard, 1992; Young, 1998). Examples given by Young and Keating (2001) for a site in northern Ecuador include Barnadesia arborea Kunth, Brachyotum ledifolium (Desr.) Triana, Coriaria ruscifolia L., Escallonia myrtilloides L. f., Gaultheria foliolosa Benth., Maytenus verticillata (Ruiz \& Pav.) DC., Monnina obtusifolia Kunth, Piper barbatum Kunth, and Vallea stipularis L. f. Surviving wildlife species are tolerant of human presence, unattractive as game, and unthreatening to human interests (Young, 1997). Most Andean species of humanized landscapes thrive in open, edge, or successional habitats.

\section{Future Geographies of the Andes: Toward a Conceptual Model}

Species persistence in the inhabited and utilized landscapes of the Andes will depend on species traits, including their sensitivity to the effects of future change in the biophysical factors that control their distribution and abundance (Scholze et al., 2006; Tewksbury et al., 2008). The effects on species also will be constrained by and mediated through changes in land cover, so LULCC will be critical. Given current global environmental changes and visible 


\section{Biophysical factors:}

$\uparrow$ Temperature

$\uparrow$ Carbon dioxide

$\downarrow$ Precipitation

$\uparrow$ Height cloud bank

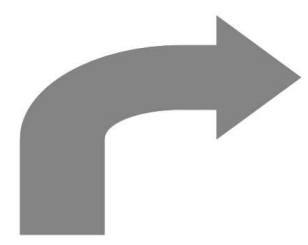

Vegetation and land cover:

Species distributions

Species abundances

Ecosystem productivity, fluxes

\section{Perceptions of climate change \\ Capacity to respond individually \\ Capacity to respond collectively}

Land use and livelihood practices:

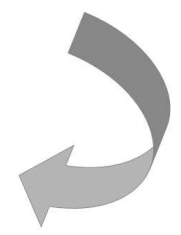

Figure 2. A conceptualization of proposed interactions and feedbacks hypothesized to connect climate change in the Andes, as mediated through biophysical changes to shifting land use and vegetation.

consequences in the high Andes in terms of reduced permanent ice and altered land cover (Ramírez et al., 2001; Vuille et al., 2003; Thompson et al., 2006; Young, 2007), plus increased natural hazards (Carey, 2005; Vilímek et al., 2005), Andean landscape mosaics will continue to shift at least over the next couple of decades. In this section, I develop a conceptual model of how landscapes are being affected and of how species distributions may be changed as a result.

Figure 2 connects the major biophysical factors that are changing in tropical latitudes to land cover and land use. Not only are temperatures increasing, driven by more greenhouse gases such as $\mathrm{CO}_{2}$, but many tropical areas are expected to have less precipitation (Cook \& Vizy, 2008). In addition, there will be upward shifts in altitudes where moisture condenses, fog frequently forms, and cloud forests are found (Foster, 2001). One important way that these environmental controls affect plants is through altered soil properties, such as soil moisture and nutrient availability.

However, the effects on land cover will not be unidirectional given the presence of land use, which can respond quickly through farmers' actions and reactions to cues in the landscape (Young \& Lipton, 2006). Thus, Figure 2 includes arrows suggesting links and feedbacks. Shifts in plant growth and composition alter grazing systems and cropping patterns. Land use will change, given the capacity to shift the locations of pastures and field, the knowledge and resources to modify planted crops, and collective or household capital that permits new livelihood strategies (Mayer, 2002) and external networks (Bebbington, 2000). For the Andes, this means that agriculture and pastoralism must change, with grazing activities moved to higher elevations on newly formed wetlands following glacial retreat and crop choice modified on thousands of agricultural fields; it also implies fewer water resources for the settlements and cities located downslope (Bradley et al., 2006). Predicting shifts of wild species will require information on the bioclimatic envelopes occupied and the additional degree of sensitivity to direct and indirect influences of land use.

The complexity of the more traditional farming systems should provide ample margins for rapid adaptation for the farmers themselves, with households often planting multiple crops and land races on 12 or more different fields, locating them at different elevations and on different exposures (Brush, 1976; Zimmerer, 1996, 1999; Young, 2008). Of course, this resilience assumes that (1) the appropriate knowledge exists and can be transmitted, (2) the needed genetic diversity is available, (3) alternative useful plant or animal stock is on hand as needed, and (4) top-down restrictions on or incentives for certain land uses and production goals by regional or national governments do not constrain household and community adaptation.

Change is constant, and much of the biological and cultural diversity to be found in the inhabited and uninhabited landscapes of the Andes is due to that 


\section{Change (warmer, drier)}

\section{Cold (wet) adapted species}

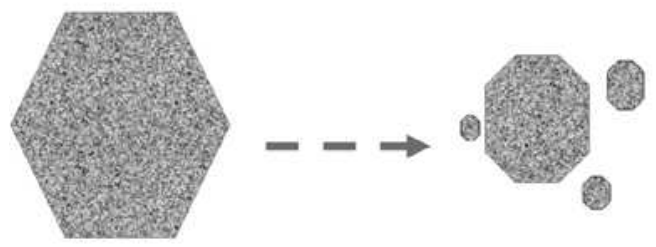

Warm (dry) adapted species

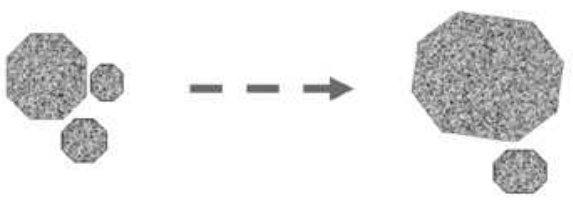

\section{Priorities}

\section{Peaks; Moist enclaves}

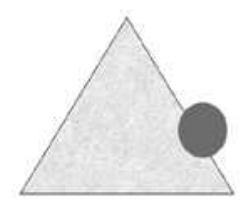

\section{Matrix}

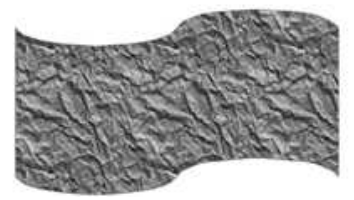

Figure 3. A conceptual model of spatial implications of future climate change in the tropical Andes for native species. The species' ranges will tend to decrease and fragment, especially for the species adapted either to relatively cold or relatively humid conditions. The converse will take place for the species adapted to relatively warm and/or dry habitats, with their potential distributions both larger and less fragmented. Given these predictions, biodiversity conservation priorities for the species with smaller ranges would need to emphasize the changing high elevations and moist microsites, while the species with larger potential ranges would instead need conservation strategies focused on Andean landscape matrix habitats.

change, whether over centuries, millennia, or millions of years. Given that future change will alter biota, vegetation, and land-use systems relatively quickly (Fig. 2), and hence mosaic-related processes, there might be ways to predict and prepare for consequences. For land use, this would require LULCC measurements that locate and calculate the new biophysical constraints acting on landscapes, while also conducting evaluations capable of elucidating the external influences acting on human decision making, including market signals, land tenure, and alternatives to rural livelihoods. It can be hypothesized that in sites with reduced precipitation or diminished glaciers, less water will require shifts by farmers from rain-fed agricultural systems to more elaborate irrigation schemes, or perhaps to more dependence on livestock such as goats and sheep.

Andean landscape geometries help set contexts and limit possibilities for the populations and metapopulations of native species, thus allowing some degree of predictability (e.g., Seabloom et al., 2002; Starzomski \& Srivastava, 2007). Small habitat patches have significant edge effect, while isolated patches have reduced gene flow and increased rates of local population extinctions. The amount of core forest habitat and the shape of forest patches change as human populations increase and land use intensifies (Kintz et al., 2006), thus likely also reducing population sizes of species requiring large core habitats (e.g., Ewers \& Didham, 2006). The rate, type, and location of habitat change in relation to intrinsic population increases of the species of concern are parameters involved in the likelihood of local extinctions (Schrott et al., 2005). The high Andean forest patches studied by Jameson and Ramsay (2007) maintained their sizes over almost 50 years but lost considerable canopy density, thus potentially negatively affecting a subset of the biota sensitive to more open conditions.

Under warmer and drier conditions, it is likely that native species needing relatively cool or wet conditions will become less common, with reduced ranges (Fig. 3). Note that the ranges not only become smaller overall, but in the rough topography of the Andes, they will often become more fragmented, with species found in smaller areas and many with local popula- 
tions in small, isolated habitat patches. Species restricted to high elevations may become extinct in at least part of their ranges (e.g., Thuiller et al., 2005), while those dependent on humid microsites (Killeen et al., 2007) may similarly be affected if those sites no longer exist. Biodiversity conservation priorities for these kinds of species should include the disappearing and unique habitats, as well as places that would permit conservation along long environmental gradients. These are here proposed to be mountain peaks, preferably contiguous to habitat along an elevational gradient, and isolated patches of cloud forest and other very humid habitats, again preferably embedded within larger areas designated for species conservation efforts (Fig. 3).

Intervention strategies for these species would need to be designed to cope with more fragmented habitats (Fig. 3), smaller populations, decreased gene flow, and increased sink habitat incapable of maintaining local populations (Pulliam, 1988; Hanski \& Ovaskainen, 2003; Ditto \& Frey, 2007, Pompe et al., 2008). The loss of species with mutualistic relationships would increase total amounts of extinctions (Koh et al., 2004; Rezende et al., 2007). As supporting evidence, Golicher et al. (2008) found that the future distributions of the montane forest flora in Chiapas, Mexico, could be evaluated in relation to two groups of species: those adapted to moist and those to cool climatic conditions. Pounds et al. (2006) assembled data suggesting that climate-caused change is the reason behind dramatic extinctions already taking place among Andean amphibians, which are exacerbated by habitat fragmentation.

Large shifts and expansions of ranges of other species are to be expected (Fig. 3). Given species' preexisting adaptations to future biophysical conditions, their distributions would often become not only larger, but less fragmented, and previously isolated populations may be brought into contact. Species that need or are tolerant of warmer conditions would be likely to be found in more sites and/or in sites occurring at higher elevations in the Andes. Species adapted to the dry exposed habitats of much of the inner Andes - the intermountain valleys - might also expand their distributions. Thus, some species will be winners in a sense, with larger potential distributions.

Biodiversity conservation strategies will still be needed, however, even for species predicted to increase their range size (Fig. 3). For example, the rare or desirable species with adaptations that would give them potentially larger ranges are here proposed to need conservation efforts that include the installation of conservation corridors permitting dispersal and the management of landscape matrices such that those species can continue to exist. Intervention strategies would need to be designed to permit species to occupy new locales through dispersal, and perhaps translocation, and to minimize noxious effects of land use in the dominant part of the landscape-the matrix. Donald and Evans (2006) recently evaluated ways that ecological restoration of matrix would help improve some ecosystem functions in agricultural landscapes; existing approaches to Andean restoration efforts (Sarmiento, 2003) would be reinvigorated with such goals.

\section{Conclusions}

Climate change will likely produce novel habitats (Williams et al., 2007), and in the Andes it will certainly produce large expanses of lands undergoing primary succession on substrates that were previously under glaciers in high mountains (Thompson et al., 2006). Change in the inhabited landscapes of the Andes will be acting on a subset of the original biota, with dangerous and nuisance species removed, and useful or beneficial species encouraged. Some of those species may be rare or absent due to historical events, not because of current biophysical conditions. Other species may be more common than expected because of their resilience to continued human impacts, such as cutting, trampling, or hunting. Still others may be present because of introduction with human migration or trade. In addition, the conceptual model in Figure 3 implies that different spatial outcomes are expected, and thus different strategies are needed for species that are predicted to lose potential distribution because they are temperature sensitive, or for species that are limited in distribution and abundance by moisture. Other species may increase their potential distributions in terms of their bioclimatic constraints (Fig. 3), but may still be of conservation concern because land-use and land-cover changes limit their actual habitat, especially in the humanized landscapes.

Conservation goals that include restoration of populations of original species and natural land cover types will need to consider what time period is to be recreated and whether that goal is desirable and attainable (Hopfensperger et al., 2007). In Europe, the use of heavy-handed management tools, such as deliberate overgrazing or frequent burning and mowing, is used to favor species restricted to open habitats or when the maintenance of early successional vegetation is a conservation objective (e.g., Moro \& Gadal, 2007). In the northwestern United States, forest management is being used to alter disturbance regimes in ways meant to maintain native biodiversity (e.g., Odion \& Sarr, 2007), while prescribed burning is used in tallgrass prairies of the central United States (Van Dyke et al., 2007). The 


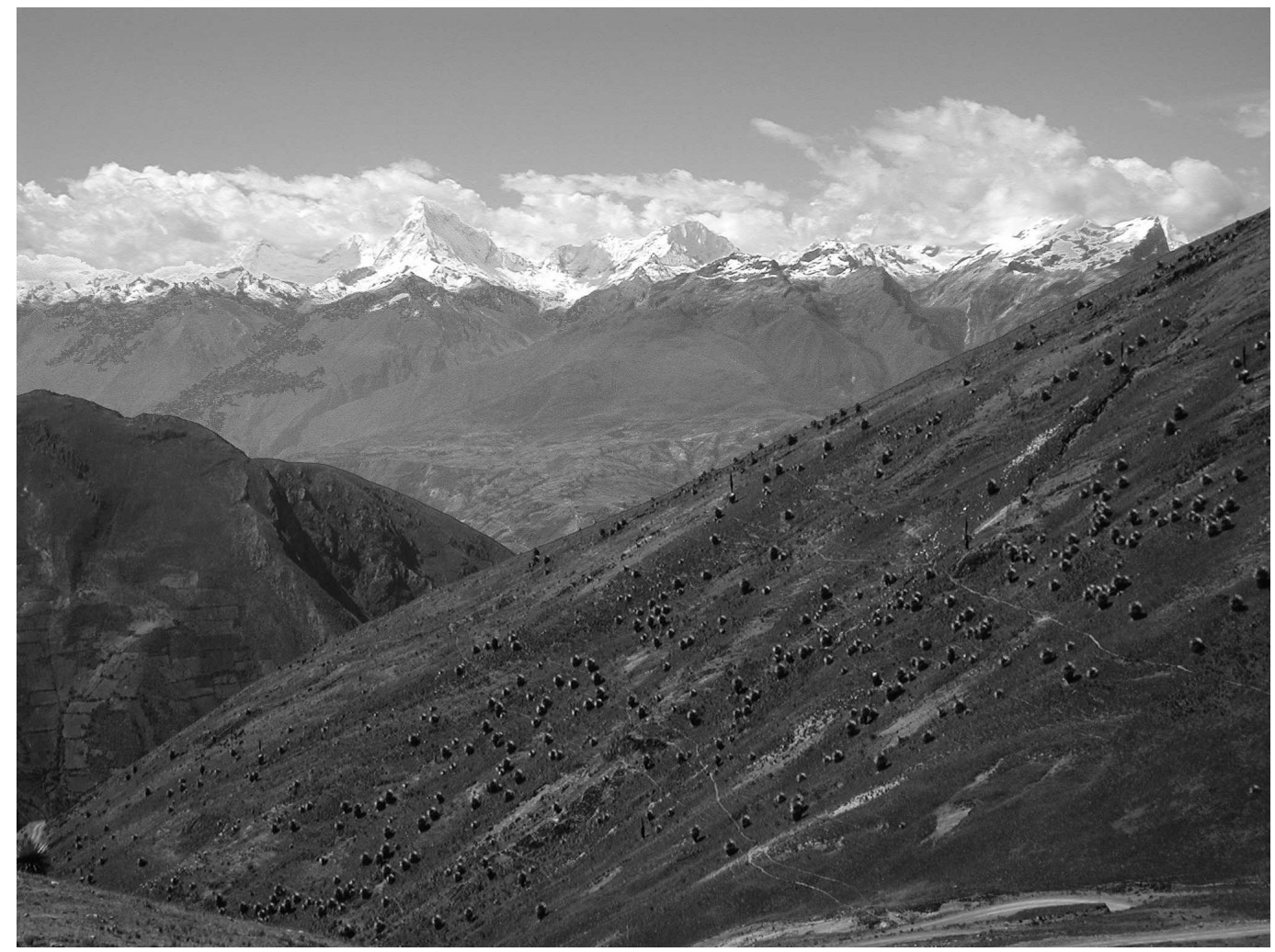

Figure 4. High Andean landscape in foreground on the Cordillera Negra of north Peru, with the glaciated Cordillera Blanca dominating the background to the east.

equivalent management options for Andean landscapes need to be designed and calibrated.

Over regional environmental gradients of humidity, elevation, and latitude, these fragmented landscapes are linked or separated by habitat and topographic connectivity (Fischer \& Lindenmeyer, 2006). Figure 4 is a landscape photograph taken in the region of Ancash in northern Peru. It shows in the foreground a stand of 5-m circumference Puya raimondii Harms growing on the Cordillera Negra, a mountain range with no permanent ice and with land-use systems dependent on seasonal rains. Similarly, mountain ranges elsewhere that are losing their glaciers are also becoming less productive for farmers who must deal with limited water (Young \& Lipton, 2006).

In the background of Figure 4, the Cordillera Blanca rises $2000 \mathrm{~m}$ higher, is capped by ice caps, and is often shrouded in clouds. People living on slopes below this range have access to water from glacial lakes and from ice melt; most use irrigation to extend growing seasons, increase agricultural productivity, and produce crops for distant markets. Changing land use will act in complex ways on the shifting habitats that contain wild native species on these two mountain cordilleras. For example, the native plants of the Cordillera Negra will be affected by both warmer temperatures and drier conditions, and livestock grazing will likely become even more extensive along that mountain range. In turn, native species of the Cordillera Blanca will have their respective potential distributions changed by climate shifts, but they will also be relocated inside the higher elevations that are within the boundaries of Huascaran National Park. The presence of a conservationprotected area makes additional conservation strategies possible, although there are likely to be increases in pressure on the park from land use extending into the park from adjacent rural communities.

Andean pastoralists often will quickly shift livestock to higher elevations as ice retreats (Young \& Lipton, 2006; Postigo et al., 2008). Every planting season, Andean farmers change or at least reevaluate what crops and what fields are to be used. Thus, certain kinds of adaptation by individual households or on lands managed communally will be quick, taking place in less than one year, unless other socioeconomic, legal, or political factors impede them (Fig. 2). Small-scale farmers studied in China by Hageback et al. (2005) showed considerable potential 
adaptation to climate change, including the diversification of livelihoods. Bates (2002) found that another common response is out-migration by people from areas under environmental stress. Relevant studies in the Andes are yet to be done. Morton (2007) worried that complex subsistence agriculture in general is not sufficiently studied in relation to climate change, and future influences on pasture species and on crops other than the major commercial species have not been research foci (Tubiello et al., 2007; Lobell et al., 2008). Policies need to promote adaptation (Howden et al., 2007), although top-down efforts may not be successful in developing countries.

Additional aspects of Andean agrobiodiversity may also require monitoring and intervention. The genotypes of traditionally used plants are threatened because of market forces, government subsidies for only a subset of the varieties, and loss of traditional knowledge (Brush, 2000). Climate change may further reduce the use of land races no longer as productive and yet containing gene complexes possibly useful under other conditions. Predicting which species or varieties will prosper under future biophysical conditions would allow institutions to foster their use and maintenance among farmers.

Humanized Andean landscapes are used in ways that favor some wild species and not others. The continued persistence of native species in these landscapes may depend as much on the patterns and dynamics of landscape mosaics as on species characteristics themselves (Danielson, 1991; Ovaskainen et al., 2002). Knowledge of current mosaic patterns, land-use change, and historical legacies will permit better understanding of landscape processes and possible conservation goals (Lunt \& Spooner, 2005). For example, the carbon found in Andean fields will have value for carbon sequestration payments (Antle et al., 2007), giving additional conservation reasons for working with agricultural landscapes. Global environmental change will shift some of the environmental continua affecting agriculture and biota, especially temperature and humidity regimes along elevational gradients. Both land-use systems and conservation efforts will need to respond spatially to these shifts in the future, at landscape and regional scales, and they should also be cognizant of the long temporal scales that gave rise to valued diversity and the changes that can cause its loss over relatively short periods.

\section{Literature Cited}

Antle, J. M., J. J. Stoorvogel \& R. O. Valdivia. 2007. Assessing the economic impacts of agricultural carbon sequestration: Terraces and agroforestry in the Peruvian Andes. Agric. Eco-syst. Environm. 122: 435-445.
Araújo, M. B., D. Nogués-Bravo, I. Reginster, M. Rounsevell \& R. J. Whittaker. 2008. Exposure of European biodiversity to changes in human-induced pressures. Environm. Sci. Policy 11: 38-45.

Bates, D. C. 2002. Environmental refugees? Classifying human migrations caused by environmental change. Populat. Environm. 23: 465-477.

Bebbington, A. 2000. Reencountering development: Livelihood transitions and place transformations in the Andes. Annals Assoc. Amer. Geogr. 90: 495-520.

Blondel, J. 2006. The "design" of Mediterranean landscapes: A millennial study of humans and ecological systems during the historic period. Human Ecol. 34: 713-729.

Bodin, O., M. Teng̈̈, A. Norman, J. Lundberg \& T. Elmqvist. 2006. The value of small size: Loss of forest patches and ecological thresholds in southern Madagascar. Ecol. Applic. 16: 440-451.

Bowman, D. M. J. S. 1998. The impact of aboriginal landscape burning on the Australian biota. New Phytol. 140: 385-410.

Bradley, R. S., M. Vuille, H. F. Diaz \& W. Vergara. 2006. Climate change: Threats to water supplies in the tropical Andes. Science 312: 1755-1756.

Brooks, C. P. 2006. Quantifying population substructure: Extending the graph-theoretic approach. Ecology 87: 864-872.

Brumfield, R. T. \& S. V. Edwards. 2007. Evolution into and out of the Andes: A Bayesian analysis of historical diversification in Thamnophilus antshrikes. Evolution 61: 346-367.

Brush, S. B. 1976. Man's use of an Andean ecosystem. Human Ecol. 4: 147-166.

(editor). 2000. Genes in the Field: On-Farm Conservation of Crop Diversity. Lewis Publishers, Boca Raton.

Bush, M. B., B. C. S. Hansen, D. T. Rodbell, G. O. Seltzer, K. R. Young, B. León, M. B. Abbott, M. R. Silman \& W. D. Gosling. 2005. A 17,000-year history of Andean climate and vegetation change from Laguna de Chochos, Peru. J. Quatern. Sci. 20: 703-714.

Butzer, K. W. 2005. Environmental history in the Mediterranean world: Cross-disciplinary investigation of causeand-effect for degradation and soil erosion. J. Archaeol. Sci. 32: 1773-1800.

Carey, M. 2005. Living and dying with glaciers: People's historical vulnerability to avalanches and outburst floods in Peru. Global Planet. Change 47: 122-134.

Carney, J. 1991. Indigenous soil and water management in Senegambian rice farming systems. Agric. Human Values 8: $37-48$.

Chepstow-Lusty, A. \& M. Winfield. 2000. Inca agroforestry: Lessons from the past. Ambio 29: 322-328.

-, M. R. Frogley, B. S. Bauer, M. B. Bush \& A. Tupayachi Herrera. 2003. A late Holocene record of arid events from the Cuzco region, Peru. J. Quatern. Sci. 18: 491-502.

Chetkiewicz, C.-L. B., C. C. St. Clair \& M. S. Boyce. 2006. Corridors for conservation: Integrating pattern and process. Annual Rev. Ecol. Syst. 37: 317-342.

Clark, D. B., D. A. Clark \& J. M. Read. 1998. Edaphic variation and the mesoscale distribution of tree species in a Neotropical rain forest. J. Ecol. 86: 101-112.

Coley, P. D. \& J. A. Barone. 1996. Herbivory and plant defenses in tropical forests. Annual Rev. Ecol. Syst. 27: 305-335.

Cook, K. H. \& E. K. Vizy. 2008. Effects of twenty-firstcentury climate change on the Amazon rain forest. J. Climate 21: 542-560. 
Dambrine, E., J.-L. Dupouey, L. Laüt, L. Humbert, M. Thinon, T. Beaufils \& H. Richard. 2007. Present forest biodiversity patterns in France related to former Roman agriculture. Ecology 88: 1430-1439.

Danielson, B. J. 1991. Communities in a landscape: The influence of habitat heterogeneity on the interactions between species. Amer. Naturalist 138: 1105-1120.

Denevan, W. M. 2001. Cultivated Landscapes of Native Amazonia and the Andes. Oxford University Press, New York.

Devictor, V. \& F. Jiguet. 2007. Community richness and stability in agricultural landscapes: The importance of surrounding habitats. Agric. Eco-syst. Environm. 120: 179-184.

Dillehay, T. D., J. Rossen, T. C. Andres \& D. E. Williams. 2007. Preceramic adoption of peanut, squash, and cotton in northern Peru. Science 316: 1890-1893.

Ditto, A. M. \& J. K. Frey. 2007. Effects of ecogeographic variables on genetic variation in montane mammals: Implications for conservation in a global warming scenario. J. Biogeogr. 34: 1136-1149.

Donald, P. F. \& A. D. Evans. 2006. Habitat connectivity and matrix restoration: The wider implications of agri-environment schemes. J. Appl. Ecol. 43: 209-218.

Dorrough, J. W., J. E. Ash, S. Bruce \& S. McIntyre. 2007. From plant neighbourhood to landscape scales: How grazing modifies native and exotic plant species richness in grassland. Plant Ecol. 191: 185-198.

Dwire, K. A., J. B. Kauffman, E. N. J. Brookshire \& J. E. Baham. 2004. Plant biomass and species composition along an environmental gradient in montane riparian meadows. Oecologia 139: 309-317.

Ellenberg, H. 1979. Man's influence on tropical mountain ecosystems in South America. J. Ecol. 67: 401-416.

Ewers, R. M. \& R. K. Didham. 2007. The effect of fragment shape and species' sensitivity to habitat edges on animal population size. Conservation Biol. 21: 926-936.

Ferrari, J. R., T. R. Lookingbill \& M. C. Neel. 2007. Two measures of landscape-graph connectivity: Assessment across gradients in area and configuration. Landscape Ecol. 22: 1315-1323.

Fine, P. V. A., I. Mesones \& P. D. Coley. 2004. Herbivores promote habitat specialization by trees in Amazonian forests. Science 30: 663-665.

Fischer, J. \& D. B. Lindenmayer. 2006. Beyond fragmentation: The continuum model for fauna research and conservation in human-modified landscapes. Oikos 112: $473-480$.

Forester, J. D., A. R. Ives, M. G. Turner, D. P. Anderson, D. Fortin, H. L. Beyer, D. W. Smith \& M. S. Boyce. 2007. State-space models link elk movement patterns to landscape characteristics in Yellowstone National Park. Ecol. Monogr. 77: 285-299.

Forman, R. T. T. 1995. Land Mosaics: The Ecology of Landscapes and Regions. Cambridge University Press, Cambridge.

Foster, D., F. Swanson, J. Aber, I. Burke, N. Brokaw, D. Tilman \& A. Knapp. 2003. The importance of land-use legacies to ecology and conservation. BioScience 53: 77-89.

Foster, P. 2001. The potential negative impacts of global climate change on tropical montane cloud forests. EarthSci. Rev. 55: 73-106.

Franklin, J. F. 1993. Preserving biodiversity: Species, ecosystems, or landscapes? Ecol. Applic. 3: 202-205.

Gade, D. W. 1999. Nature and Culture in the Andes. University of Wisconsin Press, Madison.
Garzione, C. N., G. D. Hoke, J. C. Libarkin, S. Withers, B. MacFadden, J. Eiler, P. Ghosh \& A. Mulch. 2008. Rise of the Andes. Science 320: 1304-1307.

Gentry, A. H. 1982. Neotropical floristics: Phytogeographical connections between Central and South America, Pleistocene climate fluctuations, or an accident of the Andean orogeny? Ann. Missouri Bot. Gard. 69: 557-593.

Glacken, C. J. 1976. Traces on the Rhodian Shore. University of California Press, Berkeley.

Golicher, D. J., L. Cayuela, J. B. M. Alkemade, M. GonzálezEspinosa \& N. Ramírez-Marcial. 2008. Applying climatically associated species pools to the modelling of compositional change in tropical montane forests. Global Ecol. Biogeogr. 17: 262-273.

Graf, R. F., S. Kramer-Schadt, N. Fernández \& V. Grimm. 2007. What you see is where you go? Modeling dispersal in mountainous landscapes. Landscape Ecol. 22: 853-866.

Graham, A., K. M. Gregory-Wodzicki \& K. L. Wright. 2001. Studies in Neotropical paleobotany. XV. A Mio-Pliocene palynoflora from the Eastern Cordillera, Bolivia: Implications for the uplift history of the central Andes. Amer. J. Bot. 88: 1545-1557.

Grau, H. R. 2001. Regional-scale spatial patterns of fire in relation to rainfall gradients in sub-tropical mountains, NW Argentina. Global Ecol. Biogeogr. 10: 133-146.

Graves, G. R. 1988. Linearity of geographic range and its possible effect on the population structure of Andean birds. Auk 105: 47-52.

Gutman, G., A. Janetos, C. Justice, E. Moran, J. Mustard, R. Rindfuss, D. Skole \& B. L. Turner II (editors). 2004. Land Change Science: Observing, Monitoring, and Understanding Trajectories of Change on the Earth's Surface. Kluwer, New York.

Hageback, J., J. Sundberg, M. Ostwald, D. Chen, X. Yun \& P. Knutsson. 2005. Climate variability and land-use change in Danangou watershed, China-Examples of small-scale farmers' adaptation. Climatic Change 72: 189-212.

Hanski, I. \& O. Ovaskainen. 2003. Metapopulation theory for fragmented landscapes. Theor. Populat. Biol. 64: 119-127.

Henkin, Z., L. Hadar \& I. Noy-Meir. 2007. Human-scale structural heterogeneity induced by grazing in a Mediterranean woodland landscape. Landscape Ecol. 22: 577-587.

Hope, G. \& J. Tulip. 1994. A long vegetation history from lowland Irian-Jaya, Indonesia. Paleogeogr. Palaeoclimatol. Palaeoecol. 109: 385-398.

Hopfensperger, K. N., K. A. M. Engelhardt \& S. W. Seagle. 2007. Ecological feasibility studies in restoration decision making. Environm. Managem. 39: 843-852.

Howden, S. M., J.-F. Soussana, F. N. Tubiello, N. Chhetri, M. Dunlop \& H. Meinke. 2007. Adapting agriculture to climate change. Proc. Natl. Acad. Sci. U.S.A. 104: 19691-19696.

Hughes, C. \& R. Eastwood. 2006. Island radiation on a continental scale: Exceptional rates of plant diversification after uplift of the Andes. Proc. Natl. Acad. Sci. U.S.A. 103: 10334-10339.

Ibarra-Manríquez, G. \& M. Martínez-Ramos. 2002. Landscape variation of liana communities in a Neotropical rain forest. Pl. Ecol. 160: 91-112.

Inbar, M. \& C. A. Llerena. 2000. Erosion processes in high mountain agricultural terraces in Peru. Mountain Res. Developm. 20: 72-79.

Jameson, J. S. \& P. M. Ramsay. 2007. Changes in high-altitude Polylepis forest cover and quality in the Cordillera de Vilcanota, Peru, 1956-2005. Biol. Conservation 138: 38-46.

Kareiva, P., S. Watts, R. McDonald \& T. Boucher. 2007. Domesticated nature: Shaping landscapes and ecosystems for human welfare. Science 316: 1866-1869. 
Kattan, G. H., P. Franco, C. A. Saavedra-Rodríguez, C. Valderrama, V. Rojas, D. Osorio \& J. Martínez. 2006. Spatial components of bird diversity in the Andes of Colombia: Implications for designing a regional reserve system. Conservation Biol. 20: 1203-1211.

Kemp, R., N. Branch, B. Silva, F. Meddens, A. Williams, A. Kendall \& C. Vivanco. 2006. Pedosedimentary, cultural and environmental significance of paleosols within prehispanic agricultural terraces in the southern Peruvian Andes. Quatern. Int. 158: 13-22.

Khush, G. S. 1997. Origin, dispersal, cultivation and variation of rice. Pl. Molec. Biol. 35: 25-34.

Killeen, T. J., M. Douglas, T. Consiglio, P. M. Jørgensen \& J. Mejia. 2007. Dry spots and wet spots in the Andean hotspot. J. Biogeogr. 34: 1357-1373.

Kintz, D. B., K. R. Young \& K. A. Crews-Meyer. 2006. Implications of land use/land cover change in the buffer zone of a national park in the tropical Andes. Environm. Managem. 38: 238-252.

Kitzberger, T., P. M. Brown, E. K. Heyerdahl, T. W. Swetnam \& T. T. Veblen. 2007. Contingent Pacific-Atlantic ocean influence on multicentury wildfire synchrony over western North America. Proc. Natl. Acad. Sci. U.S.A. 104: 543-548.

Koh, L. P., R. R. Dunn, N. S. Sodhi, R. K. Colwell, H. C. Proctor \& V. S. Smith. 2004. Species coextinctions and the biodiversity crisis. Science 305: 1632-1634.

Körner, C. 1999. Alpine Plant Life: Functional Plant Ecology of High Mountain Ecosystems. Springer, Berlin.

Kupfer, J. A., G. P. Malanson \& S. B. Franklin. 2006. Not seeing the ocean for the islands: The mediating influence of matrix-based processes on forest fragmentation effects. Global Ecol. Biogeogr. 15: 8-20.

Laegaard, S. 1992. Influence of fire in the grass páramo vegetation of Ecuador. Pp. 151-170 in H. Balslev \& J. L. Luteyn (editors), Páramo: An Andean Ecosystem under Human Influence. Academic Press, London.

Lambin, E. F., H. J. Geist \& E. Lepers. 2003. Dynamics of land-use and land-cover change in tropical regions. Ann. Rev. Environm. Res. 28: 205-241.

, B. L. Turner, H. J. Geist, S. B. Agbola, A. Angelsen, J. W. Bruce, O. T. Coomes, R. Dirzo, G. Fischer, C. Folke, P. S. George, K. Homewood, J. Imbernon, R. Leemans, X. Lin, E. F. Moran, M. Mortimore, P. S. Ramakrishnan, J. F. Richards, H. Skånes, W. Steffen, G. D. Stone, U. Svedin, T. A. Veldkamp, C. Vogel \& J. Xuy. 2001. The causes of land-use and land-cover change: Moving beyond the myths. Global Environm. Change 11: 261-269.

La Torre-Cuadros, M. A., S. Herrando-Pérez \& K. R. Young. 2007. Diversity and structural patterns for tropical montane and premontane forests of central Peru, with an assessment of the use of higher-taxon surrogacy. Biodivers. \& Conservation 16: 2965-2988.

Lobell, D. B., M. B. Burke, C. Tebaldi, M. D. Mastrandrea, W. P. Falcon \& R. L. Naylor. 2008. Prioritizing climate change adaptation needs for food security in 2030 . Science 319: 607-610.

Lunt, I. D. \& P. G. Spooner. 2005. Using historical ecology to understand patterns of biodiversity in fragmented agricultural landscapes. J. Biogeogr. 32: 1859-1873.

Manel, S., M. K. Schwartz, G. Luikart \& P. Taberlet. 2003. Landscape genetics: Combining landscape ecology and population genetics. Trends Ecol. Evol. 18: 189-197.

Marín, J. C., C. S. Casey, M. Kadwell, K. Yaya, D. Hoces, J. Olazabal, R. Rosadio, J. Rodriguez, A. Spotorno, M. W. Bruford \& J. C. Wheeler. 2007. Mitochondrial phylogeography and demographic history of the Vicuña: Implications for conservation. Heredity 99: 70-80.
Mayer, E. 2002. The Articulated Peasant: Household Economies in the Andes. Westview Press, Boulder.

McRae, B. H. \& P. Beier. 2007. Circuit theory predicts gene flow in plant and animal populations. Proc. Natl. Acad. Sci. U.S.A. 104: 19885-19890.

Montgomery, D. R., G. Balco \& S. D. Willett. 2001. Climate, tectonics, and the morphology of the Andes. Geology 29: $579-582$.

Moro, D. \& S. Gadal. 2007. Benefits of habitat restoration to small mammal diversity and abundance in a pastoral agricultural landscape in mid-Wales. Biodivers. \& Conservation 16: 3543-3557.

Morton, J. F. 2007. The impact of climate change on smallholder and subsistence agriculture. Proc. Natl. Acad. Sci. U.S.A. 104: 19680-19685.

Muchhala, N. \& P. Jarrín-V. 2002. Flower visitation by bats in cloud forests of western Ecuador. Biotropica 34: 387-395.

Muellner, A. N., K. Tremetsberger, T. Stuessy \& C. M. Baeza. 2005. Pleistocene refugia and recolonization routes in the southern Andes: Insights from Hypochaeris palustris (Asteraceae, Lactuceae). Molec. Ecol. 14: 203-212.

Nascimento, H. E. M., A. C. S. Andrade, J. L. C. Camargo, W. F. Laurance, S. G. Laurance \& J. E. L. Ribeiro. 2006. Effects of the surrounding matrix on tree recruitment in Amazonian forest fragments. Conservation Biol. 20: 853-860.

Noss, R. F. 1990. Indicators for monitoring biodiversity: A hierarchical approach. Conservation Biol. 4: 355-364.

Odion, D. C. \& D. A. Sarr. 2007. Managing disturbance regimes to maintain biological diversity in forested ecosystems of the Pacific Northwest. Forest Ecol. Managem. 246: 57-65.

Ohsawa, T. \& Y. Ide. 2008. Global patterns of genetic variation in plant species along vertical and horizontal gradients on mountains. Global Ecol. Biogeogr. 17: 152-163.

Ovaskainen, O., K. Sato, J. Bascompte \& I. Hanski. 2002. Metapopulation models for extinction threshold in spatially correlated landscapes. J. Theor. Biol. 215: 95-108.

Paduano, G. M., M. B. Bush, P. A. Baker, S. C. Fritz \& G. O. Seltzer. 2003. A vegetation and fire history of Lake Titicaca since the Last Glacial Maximum. Palaeogeogr. Palaeoclimatol. Palaeoecol. 194: 259-279.

Palacios, E. \& A. Rodríguez. 2001. Ranking pattern and use of space in a group of red howler monkeys (Alouatta seniculus) in a southeastern Colombian rainforest. Amer. J. Primatol. 55: 233-251.

Pärtel, M., A. Helm, T. Reitalu, J. Liira \& M. Zobel. 2007. Grassland diversity related to the Late Iron Age human population density. J. Ecol. 95: 574-582.

Pennington, R. T., G. P. Lewis \& J. A. Ratter (editors). 2006. Neotropical Savannas and Seasonally Dry Forests: Plant Diversity, Biogeography, and Conservation. The Systematics Association Special Volume Series 69. CRC, Boca Raton.

Perry, L., D. H. Sandweiss, D. R. Piperno, K. Rademaker, M. A. Malpass, A. Umire \& P. de la Vera. 2006. Early maize agriculture and interzonal interaction in southern Peru. Nature 440: 76-79.

Pirie, M. D., L. W. Chatrou, J. B. Mols, R. H. J. Erkens \& J. Oosterhof. 2006. "Andean-centered" genera in the shortbranch clade of Annonaceae: Testing biogeographical hypotheses using phylogeny reconstruction and molecular dating. J. Biogeogr. 33: 31-46.

Pitman, N. C. A., P. M. Jørgensen, R. S. R. Williams, S. León-Yánez \& R. Valencia. 2002. Extinction rate estimates for a modern Neotropical flora. Conservation Biol. 16: 1427-1431. 
Plantegenest, M., C. Le May \& F. Fabre. 2007. Landscape epidemiology of plant diseases. J. Royal Soc. Interface 4: 963-972.

Pompe, S., J. Hanspach, F. Badeck, S. Klotz, W. Thuiller \& I. Kühn. 2008. Climate and land use change impacts on plant distributions in Germany. Biol. Lett. 4: 564-567.

Postigo, J., K. R. Young \& K. A. Crews. 2008. Change and continuity in a pastoralist community in the high Peruvian Andes. Human Ecol. 36: 535-551.

Pounds, J. A., M. R. Bustamante, L. A. Coloma, J. A. Consuegra, M. P. L. Fogden, F. N. Foster, E. La Marca, K. L. Masters, A. Merino-Viteri, R. Puschendorf, S. R. Ron, G. A. Sánchez-Azofeifa, C. J. Still \& B. E. Young. 2006. Widespread amphibian extinctions from epidemic disease driven by global warming. Nature 439: 161-167.

Pulliam, H. R. 1988. Sources, sinks, and population regulation. Amer. Naturalist 132: 652-661.

Ramírez, E., B. Francou, P. Ribstein, M. Descloitres, R. Guérin, J. Mendoza, R. Gallaire, B. Pouyaud \& E. Jordan. 2001. Small glaciers disappearing in the tropical Andes: A case study in Bolivia: Glaciar Chacaltaya $\left(16^{\circ} \mathrm{S}\right)$. J. Glaciol. 47: 187-194.

Rand, T. A., J. M. Tylianakis \& T. Tscharntke. 2006. Spillover edge effects: The dispersal of agriculturally subsidized insect natural enemies into adjacent natural habitats. Ecol. Lett. 9: 603-614.

Redford, K. H. 1992. The empty forest. BioScience 42: $412-422$.

Reusch, T. B. H. \& T. E. Wood. 2007. Molecular ecology of global change. Molec. Ecol. 16: 3973-3992.

Rezende, E. L., J. E. Lavabre, P. R. Guimarães Jr., P. Jordano \& J. Bascompte. 2007. Non-random coextinctions in phylogenetically structured mutualistic networks. Nature 448: 925-928.

Rigsby, C. A., P. A. Baker \& M. S. Aldenderfer. 2003. Fluvial history of the Rio Ilave valley, Peru, and its relationship to climate and human history. Palaeogeogr. Palaeoclimatol. Palaeoecol. 194: 165-185.

Ripple, W. J., E. J. Larsen, R. A. Renkin \& D. W. Smith. 2001. Trophic cascades among wolves, elk and aspen on Yellowstone National Park's northern range. Biol. Conservation 102: 227-234.

Rodríguez-Cabal, M. A., M. A. Miasen \& A. J. Novaro. 2007. Habitat fragmentation disrupts a plant-disperser mutualism in the temperate forest of South America. Biol. Conservation 139: 195-202.

Rull, V. \& S. Nogué. 2007. Potential migration routes and barriers for vascular plants of the Neotropical Guyana highlands during the Quaternary. J. Biogeogr. 34: 1327-1341.

Salamini, F., H. Özkan, A. Brandolini, R. Schäfer-Pregl \& W. Martin. 2002. Genetics and geography of wild cereal domestication in the Near East. Nat. Rev. Genet. 3: 429-441.

Sandor, J. A. \& N. S. Eash. 1995. Ancient agricultural soils in the Andes of southern Peru. J. Soil Sci. Soc. Amer. 59: 170-179.

Sarmiento, F. O. 2003. Anthropogenic change in the landscapes of highland Ecuador. Geogr. Rev. 92: 213-234.

Schmitz, O. J. 2008. Effects of predator hunting mode on grassland ecosystem function. Science 319: 952-954.

Scholze, M., W. Knorr, N. W. Arnell \& I. C. Prentice. 2006. A climate-change risk analysis for world ecosystems. Proc. Natl. Acad. Sci. U.S.A. 103: 13116-13120.

Schrott, G. R., K. A. With \& A. W. King. 2005. On the importance of landscape history for assessing extinction risk. Ecol. Applic. 15: 493-506.
Seabloom, E. W., A. P. Dobson \& D. M. Stoms. 2002. Extinction rates under nonrandom patterns of habitat loss. Proc. Natl. Acad. Sci. U.S.A. 99: 11229-11234.

Seastedt, T. R., W. D. Bowman, T. N. Caine, D. McKnight, A. Townsend \& M. W. Williams. 2004. The landscape continuum: A model for high-elevation ecosystems. BioScience 54: 111-121.

Sergio, F. \& P. Pedrini. 2007. Biodiversity gradients in the Alps: The overriding importance of elevation. Biodivers. \& Conservation 16: 3243-3254.

Sluyter, A. 2001. Colonialism and landscape in the Americas: Material/conceptual transformations and continuing consequences. Ann. Assoc. Amer. Geogr. 91: $410-428$.

Smith, D. W., R. O. Peterson \& D. B. Houston. 2003. Yellowstone after wolves. BioScience 53: 330-340.

Spotorno, A. E., J. C. Marín, G. Manríquez, J. P. Valladares, E. Rico \& C. Rivas. 2006. Ancient and modern steps during the domestication of guinea pigs (Cavia porcellus L.). J. Zool. 270: 57-62.

Starzomski, B. M. \& D. S. Srivastava. 2007. Landscape geometry determines community response to disturbance. Oikos 116: 690-699.

Stueve, K. M., C. W. Lafon \& R. E. Isaacs. 2007. Spatial patterns of ice storm disturbance on a forested landscape in the Appalachian Mountains, Virginia. Area 39: 20-30.

Svenning, J.-C. 2001. Environmental heterogeneity, recruitment limitation and the mesoscale distribution of palms in a tropical montane rain forest. J. Trop. Ecol. 17: 97-113.

Talley, T. S. 2007. Which spatial heterogeneity framework? Consequences for conclusions about patchy population distributions. Ecology 88: 1476-1489.

Terborgh, J. 1971. Distribution on environmental gradients: Theory and a preliminary interpretation of distributional patterns in the avifauna of the Cordillera Vilcabamba, Peru. Ecology 52: 23-40.

Tewksbury, J. J., R. B. Huey \& C. A. Deutsch. 2008. Putting the heat on tropical animals. Science 320: 1296-1297.

Thompson, L. G., E. Mosley-Thompson, H. Brecher, M. Davis, B. León, D. Les, P.-N. Lin, T. Mashiotta \& K. Mountain. 2006. Abrupt tropical climate change: Past and present. Proc. Natl. Acad. Sci. U.S.A. 103: 1053610543.

Thuiller, W., S. Lavorel, M. B. Araújo, M. T. Sykes \& I. C. Prentice. 2005. Climate change threats to plant diversity in Europe. Proc. Natl. Acad. Sci. U.S.A. 102: 8245-8250.

Torres-Carvajal, O. 2007. Phylogeny and biogeography of a large radiation of Andean lizards (Iguania, Stenocercus). Zool. Scripta 36: 311-326.

Troll, C. 1968. The cordilleras of the tropical Americas: Aspects of climatic, phytogeographical and agrarian ecology. Colloq. Geogr. 9: 15-56.

Tubiello, F. N., J.-F. Soussana \& S. M. Howden. 2007. Crop and pasture response to climate change. Proc. Natl. Acad. Sci. U.S.A. 104: 19686-19690.

Turner, M. G. 2005. Landscape ecology: What is the state of the science? Ann. Rev. Ecol. Syst. 36: 319-344.

Vanbergen, A. J., A. D. Watt, R. Mitchell, A.-M. Truscott, S. C. F. Palmer, E. Ivits, P. Eggleton, T. H. Jones \& J. P. Sousa. 2007. Scale-specific correlations between habitat heterogeneity and soil fauna diversity along a landscape structure gradient. Oecologia 153: 713-725.

Van Dyke, F., J. D. Schmeling, S. Starkenburg, S. Heun Yoo \& P. W. Stewart. 2007. Responses of plant and bird communities to prescribed burning in tallgrass prairies. Biodivers. \& Conservation 16: 827-839. 
Veblen, T. T., K. R. Young \& A. R. Orme (editors). 2007. The Physical Geography of South America. Oxford University Press, Oxford.

Velázquez, E. \& A. Gómez-Sal. 2007. Environmental control of early succession on a large landslide in a tropical dry ecosystem (Casita volcano, Nicaragua). Biotropica 35: 601-609.

Vilímek, V., M. L. Zapata, J. Klimeš, Z. Patzelt \& N. Santillán. 2005. Influence of glacial retreat on natural hazards of the Palcacocha Lake area, Peru. Landslides 2: 107-115.

Vitousek, P. M. 2004. Nutrient Cycling and Limitation: Hawai'i as a Model System. Princeton University Press, Princeton.

Vuille, M., R. S. Bradley, M. Werner \& F. Keimig. 2003. 20th century climate change in the tropical Andes: Observations and model results. Clim. Change 59: 75-99.

Wardle, D. A. 2002. Communities and Ecosystems: Linking the Aboveground and Belowground Components. Princeton University Press, Princeton.

Wilcox, C., B. J. Cairns \& H. P. Possingham. 2006. The role of habitat disturbance and recovery in metapopulation persistence. Ecology 87: 855-863.

Williams, J. W., S. T. Jackson \& J. E. Kutzbach. 2007. Projected distributions of novel and disappearing climates by 2100 AD. Proc. Natl. Acad. Sci. U.S.A. 104: 5738-5742.

Young, K. R. 1997. Wildlife conservation in the cultural landscapes of the central Andes. Landscape Urb. Planning 38: 137-147.

1998. Deforestation in landscapes with humid forests in the central Andes: Patterns and processes. Pp. 75-99 in K. S. Zimmerer \& K. R. Young (editors), Nature's Geography: New Lessons for Conservation in Developing Countries. University of Wisconsin Press, Madison.

2002. Minding the children: Knowledge transfer and the future of sustainable agriculture. Conservation Biol. 16: 855-856.
2005. Andes. Pp. 47-50 in H. Geist (editor), Our Earth's Changing Land: An Encyclopedia of Land-Use and Land-Cover Change. Greenwood Publishing, Westport, Connecticut.

. 2007. Causality of current environmental change in tropical landscapes. Geogr. Compass 1: 1299-1314.

- 2008. Stasis and flux in long-inhabited locales: Change in rural Andean landscapes. Pp. 11-32 in A. Millington \& W. Jepson (editors), Land-Change Science in the Tropics: Changing Agricultural Landscapes. Springer, New York.

\& P. L. Keating. 2001. Remnant forests of Volcán Cotacachi, northern Ecuador. Arctic Antarc. Alpine Res. 33: 165-172.

\& R. J. Aspinall. 2006. Kaleidoscoping landscapes, shifting perspectives. Profess. Geogr. 58: 436-447.

- \& J. K. Lipton. 2006. Adaptive governance and climate change in the tropical highlands of western South America. Clim. Change 78: 63-102.

\& B. León. 2009. Natural hazards in Peru: Causation and vulnerability. In E. Latrubesse (editor), Natural Hazards and Human-Exacerbated Disasters in Latin America. Developments in Earth Surface Processes Series, Vol. 13. Elsevier, Amsterdam.

, C. Ulloa Ulloa, J. L. Luteyn \& S. Knapp. 2002. Plant evolution and endemism in Andean South America: An introduction. Bot. Rev. 68: 4-21.

, B. León, P. M. Jørgensen \& C. Ulloa Ulloa. 2007. Tropical and subtropical landscapes of the Andes Mountains. Pp. 200-216 in T. T. Veblen, K. R. Young \& A. R. Orme (editors), The Physical Geography of South America. Oxford University Press, Oxford.

Zimmerer, K. S. 1996. Changing Fortunes: Biodiversity and Peasant Livelihood in the Peruvian Andes. University of California Press, Berkeley.

. 1999. Overlapping patchworks of mountain agriculture in Peru and Bolivia: Toward a regional-global landscape model. Human Ecol. 27: 135-165. 